\title{
The Relationship between Reliability, Responsiveness, and Empathy Aspects with Patient Satisfaction in Pharmacy Installations at Mitra Medika Amplas Hospital
}

\author{
Daphne $^{1}$, Ida Yustina ${ }^{2}$, Deli Theo ${ }^{3}$ \\ ${ }^{1,2,3}$ Universitas Sumatera Utara, Indonesia \\ Corresponding Author: Ida Yustina
}

\begin{abstract}
As people's standard of living increases, the demand for quality health also increases. Patient satisfaction is correlated with the quality of service in the hospital. By understanding the level of patient satisfaction, hospital management can learn and improve service quality. The study aims to determine the relationship between reliability, responsiveness, and empathy aspects with patient satisfaction in Pharmacy Installations at Mitra Medika Amplas Hospital. This research was an explanatory quantitative research with cross sectional design. The sample of this study amounted to 60 people and taken by accidental sampling technique. The data obtained through interviews using a questionnaire. The results showed that the level of patient satisfaction in Pharmacy Installations at Mitra Medika Amplas Hospital on reliability aspect was $63.3 \%$, responsiveness aspect was $56.7 \%$ and empathy aspect was $81.7 \%$. Based on the result of the research, the suggestion given to the service provider in this case Mitra Medika Amplas Hospital is to improve the performance of health service especially in Pharmacy Installation service by way of monitoring and evaluating periodically with the implementation of the service, evaluating and developing human resources, and infrastructure.
\end{abstract}

Keywords: Reliability, Responsiveness, Empathy, Patient Satisfaction

\section{INTRODUCTION}

According to the World Health Organization (WHO), the hospital is an integral part of a social and health organization with the function of providing comprehensive, disease healing and disease prevention services to the community. The hospital is also a training center for health workers and a center for medical research. Based on law no. 44 of 2009 concerning hospitals, what is meant by hospitals are health service institutions that provide complete individual health services that provide outpatient, inpatient, and emergency services.

The hospital is a complex organization that uses a combination of complex and specialized scientific equipment, which is functioned by a group of trained and educated personnel in dealing with problems related to modern medical knowledge for the purpose of restoration and maintenance of good health. The outpatient installation is a functional unit that handles the admission of patients in hospitals, both those who will seek outpatient treatment or those who will be treated in the hospital.

Hospitals are medical institutions that provide comprehensive personalized medical services, including inpatients, outpatients, and emergency medical services. Hospital services cannot be separated from the support unit. Support 
units include laboratories and pharmacy services (IFRS). Pharmacy facilities are hospital support units and play an important role in the sustainability of hospital services. Poorly managed pharmacy services can disrupt hospital services. This department is the only department responsible for medicines distributed in hospitals (Regulations of the Ministry of Health of the Republic of Indonesia). Pharmaceutical services are integrated activities with the aim of identifying, preventing, resolving drug problems and health-related problems. The demands of patients and the community for improving the quality of pharmaceutical services require an expansion from the old product-oriented paradigm (drug oriented), to a new patient-oriented paradigm with a pharmaceutical service philosophy (pharmaceutical care) (Permenkes, 2016).

There are several important elements in the quality expected by patients, namely the patient must be the main priority of the organization, the patient is an important consumer and to ensure patient satisfaction it is very necessary to have high-quality services in accordance with the wishes of the patient (Tjiptono, 2014). According to Kotler et al. (2012) patient satisfaction is a feeling of pleasure and disappointment of patients as a result of a comparison between perceived achievement and expectations. Patients will be satisfied if the service they get is at least the same or exceeds the patient's expectations. Meanwhile, dissatisfaction will arise if the results (outcomes) do not meet the patient's expectations (Aziz, 2012). Al-Abri and AlBalushi (2014) wrote the article "Patient Satisfaction Survey as a Tool with Quality Improvement". Improving the quality of health care organizations. Researchers emphasize the importance of implementing patient evaluations as a strategy in preparing health care plans.

To find out the quality of service that is actually felt by consumers, there are indicators of consumer satisfaction measures that lie in the five dimensions of service quality. Some parts of the five dimensions are reliability, responsiveness, and empathy. Reliability is the ability to provide the promised service as soon as possible, accurately and satisfactorily. Performance must be in accordance with customer expectations, in the sense of timeliness, fair service to all customers without errors, sympathetic attitude and high accuracy, for example such as: drug information delivery services by pharmacists. Responsiveness is the ability to assist in providing fast (responsive) and appropriate service to customers by providing clear information. Without a clear reason, letting customers wait will lead to negative perceptions of service quality, for example, such as: patients are given fast and appropriate service; Empathy is the ability to give sincere and private attention to customers by trying to understand their desires, for example such as: friendliness of staff when serving patients with good communication, attentiveness, and understanding what is needed.

Good service quality is not only measured by the luxury of facilities, completeness of technology and physical appearance, but also from the attitude and behavior of employees who must reflect professionalism and have a high commitment. In practice, a patient satisfaction survey was conducted to improve the hospital environment, patient facilities, and facilities in the context of consumerism. Effectiveness is measured based on patient feedback to improve the skills of health care providers and practices that are still a matter of controversy. The purpose of this study is to assess the opinion of clinical staff on the results of the inpatient satisfaction survey and its usefulness in the quality improvement process, to see and assess the extent to which the results of this patient satisfaction survey are useful in the quality improvement process. The patient's satisfaction. The purpose of this survey is to assess the opinion of clinical staff on the results of the inpatient satisfaction survey and its use in the quality improvement 
process, especially feedback in the related ward.

This study analyzes the relationship between reliability, responsiveness, and empathy aspects with patient satisfaction in Pharmacy Installations at Mitra Medika Amplas Hospital. The underlying reason for this research is to determine the patient's assessment of the quality of health services and the satisfaction they can feel. This is important as an evaluation of the marketing strategy and service quality that is carried out, especially on the attitudes and behavior of the hospital's patients, related to revamping and improving the quality of services in order to provide optimal satisfaction. Based on observations and initial interviews with patients in Mitra Medika Amplas Hospital, it was found the facts that there are patients still complained about the quality of services to the hospitals. This is based on the patient's statement which revealed that most patients still feel the lack of staff services, high drug prices, respondents felt that the waiting time for taking drugs by pharmacists was too long, no clear queue number in waiting, and the officers were not friendly and patient.

\section{RESEARCH METHODS}

The type of this research is a quantitative approach with an explanatory research method. The dependent variable of this study is the patient satisfaction, and the independent variables are reliability, responsiveness, and empathy which aims to determine the relationship between reliability, responsiveness, and empathy aspects with patient satisfaction in Pharmacy Installations at Mitra Medika Amplas Hospital.

The population of this study is all users of Pharmacy Installations services in the patient unit of the Mitra Medika Amplas Hospital. The samples were taken using accidental sampling technique. The sample in this study amounted to 60 people whose are users of Pharmacy Installations services in the patient unit of the Mitra Medika Amplas Hospital. With the inclusion criteria, the respondent must be patients and/or families of patients who redeem drugs in the Pharmacy Installation at Mitra Medika Amplas Hospital, can communicate, read and write well and patients and/or families of patients at least visit the Pharmacy Installation at Mitra Medika Amplas Hospital twice.

The data collected and conducted by interviewing using questionnaires to obtain the sample identity (such as name, age, gender and work).

The analysis was carried out in research with univariate and bivariate analysis. Univariate analysis that is descriptive using a frequency distribution table. Bivariate analysis was performed using the chi-square test.

\section{RESULT AND DISCUSSION}

The results of the univariate analysis can be seen in the table below:

\begin{tabular}{|c|c|c|}
\hline \multicolumn{3}{|c|}{$\begin{array}{l}\text { Table 1: The Frequency Distribution of Respondent } \\
\text { According to Gender, Reliability, Responsiveness, an } \\
\text { Empathy Aspects and Patient Satisfaction in Pharmac } \\
\text { Installations }\end{array}$} \\
\hline Variable & $\mathbf{n}$ & $\%$ \\
\hline \multicolumn{3}{|l|}{ Gender } \\
\hline Male & 44 & 73.3 \\
\hline Female & 16 & 26.7 \\
\hline Amount & 60 & 100 \\
\hline \multicolumn{3}{|l|}{ Reliability } \\
\hline Good & 38 & 63.3 \\
\hline Poor & 22 & 36.7 \\
\hline Amount & 60 & 100 \\
\hline \multicolumn{3}{|l|}{ Responsiveness } \\
\hline Good & 34 & 56.7 \\
\hline Poor & 26 & 43.3 \\
\hline Amount & 60 & 100 \\
\hline \multicolumn{3}{|l|}{ Empathy } \\
\hline Good & 46 & 76.7 \\
\hline Poor & 14 & 23.3 \\
\hline Amount & 60 & 100 \\
\hline \multicolumn{3}{|c|}{ Patient Satisfaction } \\
\hline Yes & 37 & 61.7 \\
\hline No & 23 & 38.3 \\
\hline Amount & 60 & 100 \\
\hline
\end{tabular}

From Table 1 we can see the distributions of respondents. There are 44 people $(73.3 \%)$ respondents is male, and 16 people $(26.7 \%)$ respondents are female. The results showed that the level of patient satisfaction in Pharmacy Installations at Mitra Medika Amplas Hospital on reliability was $63.3 \%$, responsiveness was $56.7 \%$ and empathy was $76.7 \%$. The 
distribution of patient satisfaction in Pharmacy Installations at Mitra Medika Amplas Hospital is $61.7 \%$.

Mitra Medika Amplas Hospital is one of the private hospitals in Medan City which is privately owned under the auspices of PT. Human Medical Partners. In 2018 to be exact on December 31, 2018 Mitra Medika Amplas Hospital has successfully completed the accreditation process for the national hospital accreditation standard (SNARS) with the plenary predicate. This achievement is very grateful considering the Mitra Medika Amplas Hospital is the first hospital in North Sumatra that has succeeded in obtaining the plenary predicate for the national standard for hospital accreditation (SNARS).

Table 2: The Relationship between Reliability, Responsiveness, and Empathy Aspects with Patient Satisfaction in Pharmacy Installations at Mitra Medika Amplas Hospital

\begin{tabular}{|c|c|c|c|c|c|c|c|}
\hline \multirow[t]{3}{*}{ Variable } & \multicolumn{4}{|c|}{ Patient Satisfaction } & & & \multirow{3}{*}{ P-Value } \\
\hline & \multicolumn{2}{|c|}{ Yes } & \multicolumn{2}{|c|}{ No } & \multicolumn{2}{|c|}{ Amount } & \\
\hline & $\mathbf{n}$ & $\%$ & $\mathbf{n}$ & $\%$ & $\mathbf{N}$ & $\%$ & \\
\hline \multicolumn{8}{|l|}{ Reliability } \\
\hline Good & 29 & 76.3 & 9 & 23.7 & 38 & 100 & \multirow[t]{3}{*}{0.002} \\
\hline Poor & 8 & 36.4 & 14 & 63.6 & 22 & 100 & \\
\hline Amount & 37 & 61.7 & 23 & 38.3 & 60 & 100 & \\
\hline \multicolumn{8}{|c|}{ Responsiveness } \\
\hline Good & 26 & 76.5 & 8 & 23.5 & 34 & 100 & \multirow[t]{3}{*}{0.007} \\
\hline Poor & 11 & 42.3 & 15 & 57.5 & 26 & 100 & \\
\hline Amount & 37 & 61.7 & 23 & 38.3 & 60 & 100 & \\
\hline \multicolumn{8}{|l|}{ Empathy } \\
\hline Good & 33 & 71.7 & 13 & 28.3 & 46 & 100 & \multirow[t]{3}{*}{0.004} \\
\hline Poor & 4 & 28.6 & 10 & 71.4 & 14 & 100 & \\
\hline Amount & 37 & 61.7 & 23 & 38.3 & 60 & 100 & \\
\hline
\end{tabular}

Table 2 is bivariate with the chisquare test. It shows that there are 29 patients who satisfied with the reliability aspect, there are 26 patients who satisfied with the responsiveness aspect, and there are 33 who satisfied with the empathy aspect with patient satisfaction in Pharmacy Installations at Mitra Medika Amplas Hospital. From this table, we can see that there is a relationship between reliability aspect $(\mathrm{p}=0.002)$ with patient satisfaction in Pharmacy Installations at Mitra Medika Amplas Hospital. It means that the service is easy and uncomplicated, the prescribed medicine is always available, and the officer explains how to use the medicine.

There is a relationship between responsiveness aspect $(\mathrm{p}=0.007)$ with patient satisfaction in Pharmacy Installations at Mitra Medika Amplas Hospital. It means that the patient is satisfied with the officer immediately prepares the medicine, the waiting time for the medicine is short and there is a clear waiting queue number. There is a relationship between empathy aspect $(\mathrm{p}=0.004)$ with patient satisfaction in Pharmacy Installations at Mitra Medika Amplas Hospital. This means that patients are satisfied because the officers in installation pharmacy are friendly and patient, the officers are polite and respectful with patients, and the officers communicate (provide information) well.

This result is relevant with Harun's research (2019) shows that there is a relationship between patient satisfaction dimensions, namely reliability (0.023), responsiveness (0.018), assurance (0.009), empathy (0.005), tangibles (0.0005) with patient satisfaction in inpatient PKM Pasaman Regency in 2019. Research by Lita et al. (2016) states that service quality affects patient satisfaction, namely the perception of direct evidence $(\mathrm{p}=0.038 \mathrm{Exp}$ $(B)=0.485)$, and the perception of costs $(\mathrm{p}=0.010 \operatorname{Exp}(\mathrm{B})=0.381)$. Saeed et al (2018) also stated that in a meta-analysis study, it was stated that there was an effect of the quality of health services (tangibles, reliability, assurance, empathy and responsibility) with patient satisfaction $(p<0.01)$. This can be seen from the negative service quality dimension, which states that the quality of health services in Iran has not satisfied patients and needs to be improved.

Pareraway (2016) shows that all dimensions of service quality on outpatients satisfaction in pharmacy at the Pharmacy Installation of RSUP Prof. Dr. R. D Kandou Manado shows a negative gap value, this means that the services provided by the outpatient Pharmacy Installation to outpatient customers are still not 100 percent satisfactory. Overall, the average level of satisfaction of the Pharmacy Installation of RSUP Prof. Dr. R. D Kandou 
of outpatient customers studied is $80 \%$, this shows that there are still around $20 \%$ of respondents who are dissatisfied with the Pharmacy Installation service. Tangible dimension (facility) shows the highest level of satisfaction, followed by assurance (belief) then responsiveness and empathy feel at the same average level of satisfaction and the last reliability which is the lowest average satisfaction level of the five dimensions.

Reliability is one of the five dimensions of service quality, and according to Tjiptono (2006) that service quality is closely related to satisfaction, where good quality will provide an experience for customers and will further invite them to come back for their next visit and become loyal customers. The relationship between reliability and patient satisfaction is that reliability has a positive and significant effect on patient satisfaction. The better the customer's perception of reliability, the higher the patient's satisfaction where if the patient's perception of reliability is bad, the lower the patient's satisfaction. Andriani, (2017) in his research regarding the Relationship between health service quality and patient satisfaction in the Bukit Tinggi Public Polyclinic Room. The results were obtained from respondents who had high service quality, there were more than most of the respondents who had a percentage $(58.5 \%)$ of respondents who feel satisfied and have a quality that exceeds the absence of half of that number in the percentage (36.9\%) getting satisfaction. Based on the statistical test obtained $p$-value $=0.035$ so when compared with $\mathrm{a}=0.10$, the $\mathrm{p}$ value $<\mathrm{a}$ $(0.035<0.10)$ it can be concluded that there is a correlation between the provisions of public health conditions and the satisfaction of balehin inpatients 2014, proves that speed in the administrative process has a positive effect on perceptions of hospital reliability. Likewise, research conducted by Yusuf (2012) on inpatients at Anutapura Hospital, Palu City, showed that the better the reliability, the greater the patient's satisfaction with hospital services.
The more responsive the service, the more satisfied the assessment of the outpatient patient/client of nursing care services will be. According to Griffith (2007), in order to increase loyalty, it can be done by adding value to what is offered, adding value can be done by increasing the speed of service. For a hospital, it is very important to have officers, especially nurses who are responsive in serving customers/ patients, because nurses are hospital resources who interact with patients the most. Responsiveness of officers in serving patients/clients is closely related to patient satisfaction. The relationship between responsiveness and patient satisfaction is that responsiveness has a positive and significant effect on patient satisfaction. The better the customer's perception of responsiveness, the higher the patient's satisfaction, and if the patient's perception of the responsiveness is bad, the lower the patient's satisfaction. In accordance with the opinion of Leboeuf (2012), that responsiveness as an attitude of responsiveness of employees to serve when needed by patients is closely related to customer satisfaction. This was also obtained by Ardani and Supartiningsih (2017) in their research on the effect of service quality on satisfaction and WOM at Wangaya Hospital Denpasar, that responsiveness is the dominant factor in patient satisfaction at Wangaya Hospital Denpasar.

The patient's assessment that empathy is not satisfied, especially in terms of the officers not listening carefully to the patient's complaints, so that the patient feels his needs are not being responded to. A patient who feels cared for by the officer will create a sense of satisfaction in the patient, then the customer/patient will try to remember the name and face of the nurse and it is possible that after leaving the hospital the customer/patient will maintain a good relationship with the officer. The relationship between empathy and patient satisfaction is that empathy has a positive and significant effect on patient satisfaction. 
The better the customer's perception of empathy, the higher the patient's satisfaction, and if the patient's assessment of care is bad, the lower the patient's satisfaction. In accordance with the opinion of Muninjaya (2011) on the importance of the dimension of empathy in providing quality services. This is in line with the research of Rattoe (2013) regarding the relationship between service quality and the decision to revisit at Bethesda Tomohon General Hospital which found that the empathy variable has a very dominant influence on patient satisfaction. Furthermore, research from Moniung (2014), found that the empathy variable was closely related to the creation of quality services. Quality service can provide a good experience for customers and will invite them to come back and become loyal customers. In accordance with the opinion of Tjiptono (2014) on the importance of the dimension of empathy in providing quality services. This is in line with the research by Puspitasari and Edris (2011) regarding patient satisfaction at the Inpatient Family Healthy Hospital Pati who found that the empathy variable had a very dominant influence on patient satisfaction. Research on Patient Loyalty in Inpatient Bhayangkara Mappa Oudang Hospital Makassar City by Berlianty et al (2013) found that the empathy variable is closely related to the creation of quality services. Quality service can provide a good experience for customers and will invite them to come back and become loyal customers.

\section{CONCLUSION}

The conclusion from this study can be said that the we can see that there is a relationship between reliability aspect $(\mathrm{p}=0.002)$ with patient satisfaction in pharmacy installations at Mitra Medika Amplas Hospital, there is a relationship between responsiveness aspect $(\mathrm{p}=0.007)$ with patient satisfaction in Pharmacy Installations at Mitra Medika Amplas Hospital, and there is a relationship between empathy aspect $(\mathrm{p}=0.004)$ with patient satisfaction in Pharmacy Installations at Mitra Medika Amplas Hospital. The quality of pharmaceutical services also influences patient satisfaction. Drug services covered include pharmacy locations, staff attitudes, timeliness of service, provision of drug information and training, and availability of drugs. The availability of drugs is an important determinant of the quality of drug services to meet the satisfaction of ambulatory patients. This is based on factual reasons. After the treatment, the patient can take the medicine at home without having to buy it from another pharmacy. Most respondents were satisfied with the pharmaceutical services provided at this hospital.

\section{Acknowledgement: None}

\section{Conflict of Interest: None}

\section{Source of Funding: None}

\section{REFERENCES}

1. Ahmad, Sjafii. (2009). Undang-undang Republik Indonesia No. 44 Tahun 2009 Tentang Rumah Sakit. Jakarta: Departemen Kesehatan Republik Indonesia.

2. Al-Abri, R \& A. Al-Balushi. (2014). Patient Satisfaction Survey as a Tool Towards Quality Improvement. Oman Medical Journal, 29(1):3-7, DOI 10. 5001/omj.2014. 02.

3. Andriani, A. (2017). Hubungan Mutu Pelayanan Kesehatan Dengan Kepuasan Pasien Diruangan Poliklinik Umum Puskesmas Bukittinggi.

4. Aziz, A. (2012). Analisis Tingkat Kepuasan Pasien Terhadap Pelayanan Keperawatan Prima di RSUP DR. Djamil Padang Tahun 2012. Skripsi, Universitas Andalas, Manajemen Keperawatan, Padang.

5. Berlianty, Alwy, N. (2013). Analisis Loyalitas Pasien Berdasarkan Kualitas Pelayanan di Instalasi Rawat Inap RS. Bhayangkara Mappa Oudang Kota Makassar Tahun 2013. Bagian AKK Fakultas Kesehatan Masyarakat Universitas Hasanuddin, 12.

6. Harun, H. (2020). Analisis Faktor Yang Mempengaruhi Mutu Pelayanan Kesehatan 
Daphne et.al. The relationship between reliability, responsiveness, and empathy aspects with patient satisfaction in Pharmacy Installations at Mitra Medika Amplas Hospital

Terhadap Kepuasan Pasien di Puskesmas Rawat Inap Kabupaten Pasaman 2019. Human Care Journal, 4(3):138, https://doi. org/10.32883/hcj.v4i3.500.

7. Kotler, Philip \& Gary Armstrong. (2012). Principles of Marketing. New Jersey: Prentice-Hall Published.

8. Moniung, S. Y., R. Rondonuwu, \& Bataha, Y. B. (2014). Hubungan Tekanan Darah Sistolik dengan Kualitas Tidur Pasien Hipertensi di Puskesmas Bahu Manado. Jurnal keperawatan, 2(2).

9. Muninjaya, A. A. G. (2011). Manajemen Kesehatan. Jakarta: EGC.

10. Pangerapan, D. T. (2018). Hubungan Antara Mutu Pelayanan dengan Kepuasan Pasien di Poliklinik Penyakit dalam Rumah Sakit Umum Gmim Pancaran Kasih Manado. 2(1), 9-18, retrieved from https://ejournal.unsrat.ac.id/index.php/jkk/ar ticle/viewFile/18836/18386.

11. Pareraway, D. C. (2016). Analisis Kepuasan Pasien Rawat Jalan dalam Pelayanan Kefarmasian di Instalasi Farmasi RSUP Prof. Dr. R. D. Kandou Manado. Pharmacon, 5(4), 273-279, https://doi.org/ 10.35799/pha.5.2016.14050.

12. Permenkes. (2016). Peraturan Menteri Kesehatan Republik Indonesia Nomor 72 Tahun 2016 Tentang Standar Pelayanan kefarmasian di Rumah Sakit. Jakarta: Kementrian Kesehatan Republik Indonesia.

13. Puspitasari, M. G \& M. Edris. (2011). Pengaruh Kualitas Layanan Terhadap
Loyalitas dengan Mediasi Kepuasan Pasien Rawat Inap pada Keluarga Sehat Hospital Pati. Analisis Manajemen, 5(2).

14. Rattoe, A. (2013). Analisis Hubungan Antara Mutu Pelayanan dengan Keputusan Kunjungan Ulang Pasien Rawat Jalan di RSU Bethesda Kota Tomohon. Tesis, Program Pascasarjana, Universitas Sam Ratulangi, Manado.

15. Siahaan, S. M., Hakim, L., \& Hariyanti, T. (2018). The Effect of the Quality of Pharmaceutical Service on Outpatient Satisfaction of Amelia Hospital. Jurnal Aplikasi Manajemen, 16(1):115-124, https://doi.org/10.21776/ub.jam.2018.016.0 1.14 .

16. Supartiningsih. (2017). Kualitas Pelayanan dan Kepuasan Pasien Rumah Sakit: Kasus Pada Pasien Rawat Jalan. Jurnal Medicoeticolegal dan Manajemen Rumah Sakit, 6(1):9-15.

17. Tjiptono, F. (2014). Pemasaran Jasa, Prinsip, Penerapan, dan Penelitian. Jogyakarta: Andi Publisher.

How to cite this article: Daphne, Yustina I, Theo D. The relationship between reliability, responsiveness, and empathy aspects with patient satisfaction in Pharmacy Installations at Mitra Medika Amplas Hospital. International Journal of Science \& Healthcare Research. 2021; 6(3): 99-105. DOI: https://doi.org/ 10.52403/ijshr.20210717 